\title{
Use of Numerical Groundwater Modeling to Assess the Feasibility of Aquifer Storage and Recovery (ASR) in the Wadi Watir Delta, Sinai, Egypt
}

\author{
Osama M. Sallam \\ Research Institute for groundwater, National Water Research Center, Cairo, Egypt \\ Email: sallamosama@hotmail.com
}

How to cite this paper: Sallam, O.M. (2019) Use of Numerical Groundwater Modeling to Assess the Feasibility of Aquifer Storage and Recovery (ASR) in the Wadi Watir Delta, Sinai, Egypt. Journal of Water Resource and Protection, 11, 1462-1480. https://doi.org/10.4236/jwarp.2019.1112085

Received: October 12, 2019

Accepted: December 3, 2019

Published: December 6, 2019

Copyright $\odot 2019$ by author(s) and Scientific Research Publishing Inc. This work is licensed under the Creative Commons Attribution International License (CC BY 4.0).

http://creativecommons.org/licenses/by/4.0/

(c) (i) Open Access

\begin{abstract}
The lack of water resources in Egypt's Sinai Peninsula is a major constraint for further socioeconomic development, and flash floods in this region can damage roads and infrastructure. The Wadi Watir basin is the main water source for the groundwater aquifer, which supplies fresh water to Nuweiba city, where demands for groundwater are increasing. The objective of this research was to assess the hydrogeological suitability of installing Aquifer Storage and Recovery (ASR) systems in the Wadi Watir delta by using numerical groundwater models. The developed models were used to evaluate the effects of hydrogeological and operational parameters on the recovery efficiency of ASR systems at five potential locations in the study area. As the estimation of recovery efficiency depends on the salinity of recovered water, the recovered water salinity limit was assumed as $150 \%$ of the injected water salinity, where $150 \%$ refers to the point at which recovery has ended because the concentration of recovered water reached $150 \%$ of that of injected water. The most important output from the model runs was that the recovery efficiency of these ASR systems ranged from $25 \%$ to $54 \%$ with a longitudinal dispersivity of 10 $\mathrm{m}$, volume of injected water of $12,000 \mathrm{~m}^{3}$, and storage period of 180 days. The main conclusions are as follows. 1) Using coupled numerical groundwater flow and solute transport models is an effective tool for predicting the effects of mixing between injected water and ambient groundwater in ASR systems. 2) The groundwater aquifer in the study area is not suitable as strategic area for ASR systems because the thickness of the water storage layer is relatively small and the distance to the sea is very close; consequently, it is recommended that artificial recharge systems be developed with existing technology to replenish the groundwater aquifer in the Wadi Watir delta.
\end{abstract}




\section{Keywords}

Aquifer Storage and Recovery (ASR), Groundwater Modeling, Wadi Watir, Sinai, Egypt, Recovery Efficiency

\section{Introduction}

Rapid population growth, global climate change, and poor governance are negatively affecting available water resources in many areas [1]. One of the most important water sources in the world is groundwater, and more than one and half billion people depend on it [2]. The natural and regular recharge of groundwater aquifers happens slowly, and if the pumping rate is greater than the natural recharge, groundwater levels will decrease and degradations in quality can occur. Presently, the artificial recharge of groundwater aquifers has become an important way to enhance and increase groundwater storage [3].

A lack of water resources is a pressing concern in the Sinai Peninsula of Egypt, where this represents a major constraint for further socioeconomic development. Furthermore, flash flooding in some Wadis of the southern Sinai region has damaged roads and infrastructure. Recently, the Egyptian government has taken various steps to harvest the flash flood waters in Sinai to use the water to meet development demands while minimizing the negative effects of flash floods. In this respect, Wadi Watir in the southern Sinai region has received special attention over the past few years. The Wadi Watir basin is the main water source for the groundwater aquifer of the study area, and this aquifer is the major source of fresh water to Nuweiba city, which is located in the southeastern part of the Wadi Watir delta and is facing increasing demands for groundwater due to the rapid development [4]. Figure 1 shows the location of the Wadi Watir delta.

Groundwater in the Wadi Watir delta flows as a thin layer of fresh water, and the groundwater here is very sensitive to pumping because of its location near the coast and consequent seawater intrusion (in particular, it is affected by the upwelling of deep saline deep groundwater) [5] [6]. In 1986, the Desert Research Center published a comprehensive water budget study for the Wadi Watir delta. The main recommendations of this study were to build some underground reservoirs to store a portion of the runoff in the eastern parts of the Wadi Watir delta, and to direct a considerable portion of the surface runoff by suitable means to recharge the groundwater aquifer in the western part of the delta. In addition, the study recommended that a numerical groundwater modeling approach be used for the proper management of fresh water resources in the Wadi Watir delta [7].

Storing water in groundwater aquifers for future use is defined as Aquifer Storage and Recovery (ASR), and this technology has been in use since the late 1960s, mostly in coastal areas of the USA [8]. In ASR systems, the surplus water 


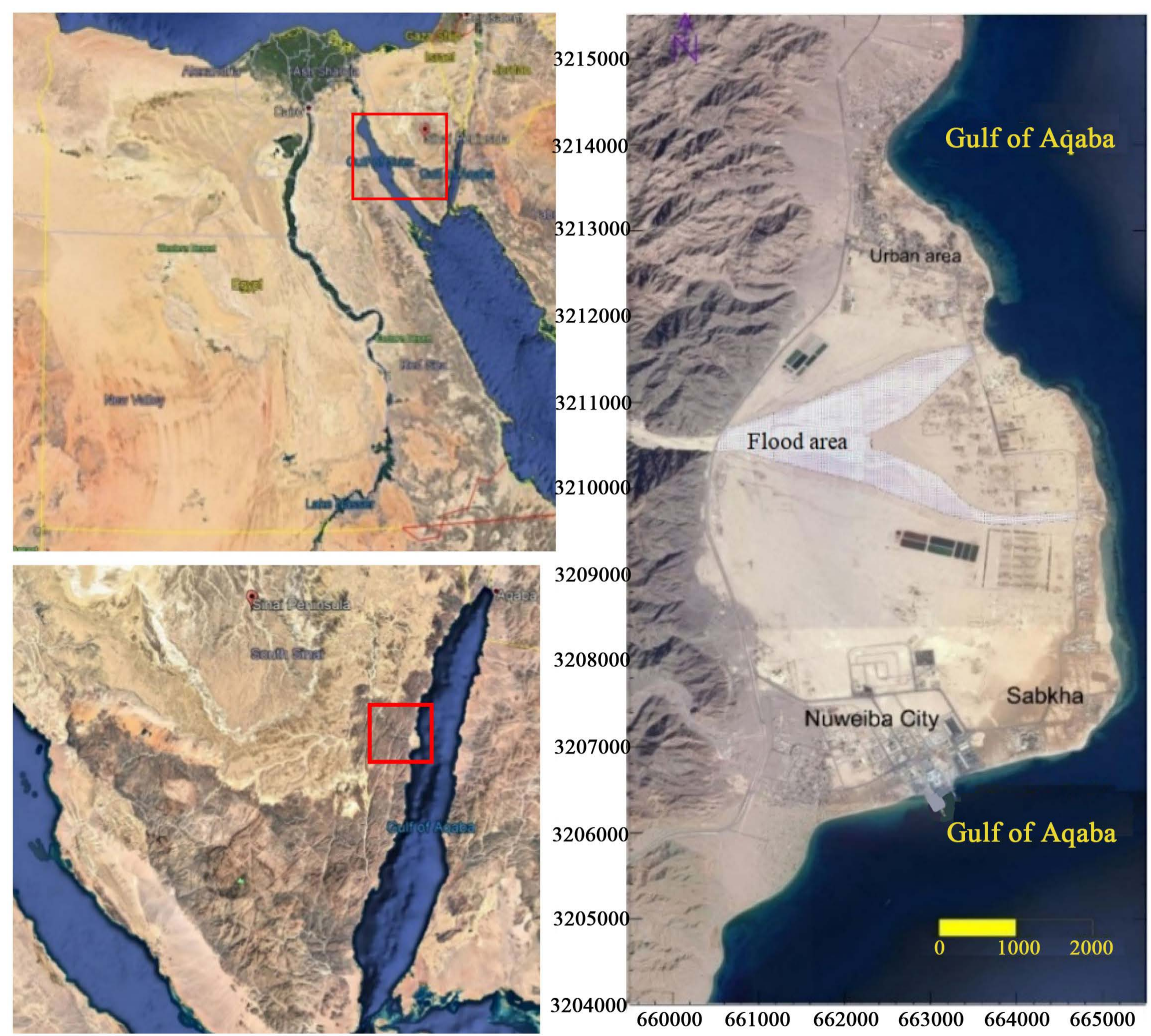

Figure 1. Location map of the Wadi Watir delta. The flood zone is located in the middle. There is a residential area in the north, and the city of Nuweiba is located in the south.

is injected into groundwater aquifers, and then, the water becomes mixed up with ambient groundwater, thereby creating "bubble" or "bottle brush" water as recently termed because of the heterogeneity of the aquifer [9]. When the demand increases, the injected water can be recovered, and in such cases, the percentage of recovered water after injection is termed the "recovery efficiency". Compared to surface reservoirs, use of ASR systems can provide for large water storage capacities, prevent seawater intrusion, and avoid many of the problems associated with surface water storage systems (e.g., harmful algal blooms) [8] [10]. There are many methods have been used to conduct preliminary evaluations of the hydrogeological parameters and their impact on the suitability of a groundwater aquifer for artificial recharge or ASR. One common method is Multi Criteria Decision Analysis (MCDA), but this method can be difficult to implement if there are insufficient hydrogeological data or when the area of assessment is very large [11]; therefore, more accurate quantitative assessment techniques are necessary, such as those involving numerical groundwater flow and transport models.

Socioeconomic development in the southern Sinai region is increasing, and thus, demands for water are expected to increase as well. In particular, there will be an urgent need for water storage of either surplus water or flood waters. This stored water can be used during peak periods of water demand or during drinking water emergencies. The objective of this research was to assess the hydro- 
geological suitability of installing ASR systems in the Wadi Watir delta of South Sinai in Egypt by using numerical groundwater models to achieve a better understanding of the aquifer parameters and operational parameters that control the system efficiency. The specific goals of this research were as follows:

- Review the available literature and previous studies on the geophysics, geology, and hydrogeology of the Wadi Watir delta aquifer.

- Develop a numerical groundwater model to simulate and calculate the aquifer recharge, pumping rates, and potential for seawater intrusion near the coast, as well as to simulate the vertical movement and migration of deep saline groundwater upward due to over pumping in the Wadi Watir delta.

- Use the developed model to evaluate the effects of hydrogeological parameters on the recovery efficiency of potential ASR systems; these parameters included the hydraulic conductivity, hydraulic gradient, effective porosity, and dispersion; additionally, operational parameters such as the volume of injected water and storage period time were evaluated.

\section{Literature Review}

The technology for ASR systems was pioneered in the 1960s in the USA, specifically, along the coastal areas of Florida and California. In 2005, 72 ASR systems were operational in the USA and approximately 100 systems were under study [12]. Presently, ASR systems are in use worldwide and numerous examples have been described in the literature, such as those installed in the Atlantic Coastal Plain [13] [14] [15] and in Charleston, South Carolina [16] [17]. In 2018, the Emirate of Abu Dhabi launched a mega project to store surplus desalinated water in the Liwa aquifer (ASR), where it is considered the world's largest storage site for desalinated water in groundwater aquifers; this project aims to supply the Emirate with drinking water during emergency periods [18].

Many researchers have discussed ASR suitability assessments at specific locations by ranking systems in terms of technical considerations, costs, and regulatory components [19] [20] [21] [22] [23]. Chowdhury et al. (2010) used the MCDA technique, satellite imagery, and a geographic information system (GIS) to delineate Potential zones of artificial recharge within an approximately 4500 $\mathrm{km}^{2}$ area in West Bengal [24]. Hill (1997) used technical considerations, costs, and regulatory components to develop a screening tool to determine how ASR technology can assist with supply and storage water objectives [25]. Rashid et al. (2005) carried out detailed evaluations that included costs, the recharge water source, the storage volume, and plant operating costs to support economic decisions aimed at balancing the desalinated water production and demand [26].

A few research studies are available online that involve the use of physical and numerical models of groundwater as tools for evaluating the suitability of aquifers for the application of ASR systems. Kimbler et al. (1975) used physical laboratory models [27], while Yobbi (1996) used numerical modeling to assess the effects of fresh water injection into a saline coastal aquifer in Florida [28]. Streetly (1998) used a modeling technique to assess the effects of fresh water in- 
jection into fresh groundwater aquifers [29]. Moulder (1970) and Merritt (1986) classified the parameters that control the recovery efficiency of fresh water injected into saline aquifers by using three categories of features, namely, the stratification density, dispersion of the fresh and saline interface, and nature of groundwater flow [30] [31]. Ward et al. (2009) simplified the need for complex data from numerical groundwater models used in ASR injection studies within brackish groundwater aquifers by developing a predictive tool based on dimensionless values representing the lateral flow, dispersive mixing, mixed convection, and free convection. This method, however, necessitates information on the hydraulic conductivities in the vertical and horizontal direction, aquifer thickness, hydraulic gradient, and density of injected and ambient water [22]. Bakker et al. (2010) developed a numerical model to evaluate the recovery efficiency of ASR wells penetrating into a saltwater aquifer [32]. Pavelic et al. (2005) used FEFLOW software to develop a numerical simulation model to explore the dynamics of the injected water plume for a number of Aquifer Storage Transfer and Recovery ASTR scenarios [33].

\section{Materials and Methods}

\subsection{Study Area}

The Wadi Watir is one of the main wadis in the region of the Aqaba rift province of the Sini Peninsula in Egypt, and it is located between Taba in the north and Sharm El-Sheikh city in the south. The Wadi Watir basin is an important water resource area for Nuweiba city, which is located on its delta. The Wadi Watir basin is bounded by the range of basement mountainous to the west and the shoreline of the Gulf of Aqaba to the east [34]. The catchment area of Wadi Watir $\left(3860 \mathrm{~km}^{2}\right)$ has a steep mountainous topography that consists of 12 sub-basins and about 32 main wadis, which drain toward the Gulf of Aqaba. High flows occur here mainly during two main storm periods, one in spring and the other in autumn. There are 5 to 10 rainy days per year with a mean annual rainfall amount ranging from 30 to $40 \mathrm{~mm}$, and the bulk of the volume of rainwater falls within a period of a few hours [35]. Annually, the amount of rainfall affecting the Wadi Watir catchment areas is about 200 million $\mathrm{m}^{3} / y e a r$. The major proportion of this rainfall is lost to the Gulf of Aqaba as surface water runoff because of the steep nature of the surface topography and the dominant presence of hard rocks; Table 1 shows historical information for flash flood occurrences and volumes in this region [35] [36].

\subsection{Aquifer Hydrogeology}

Quaternary deposits constitute the main water-bearing formation (Quaternary aquifer) in the Wadi Watir delta. This aquifer is unconfined, heterogeneous, and composed mainly of fine to coarse sands, gravels, sandstone, boulders of carbonate, and granitic rock embedded in a clay and silt matrix [37] [38]. The Quaternary aquifer in the study area can be categorized into five layers, and the 
Table 1. Flash flood occurrence and volume modified after Cools et al. (2012). It is important to note that during the last 33 years, very high floods occurred 2 times in the years 1987 and 1997, and high floods occurred 5 times in the years 1988, 1990, 1993, 1997, and 2010; additionally, moderate floods occurred 7 times in the years 1988, 1991, 1994 to 1997 , and 2002.

\begin{tabular}{|c|c|c|c|c|c|}
\hline Flood Data & $\begin{array}{l}\text { Volume } \\
\left(10^{6} \mathrm{~m}^{3}\right)\end{array}$ & Flash Flood & Flood Data & $\begin{array}{l}\text { Volume } \\
\left(10^{6} \mathrm{~m}^{3}\right)\end{array}$ & Flash Flood \\
\hline 16 Oct 1987 & 45 & Very High & 16-17 May 1997 & 4.4 & Moderate \\
\hline 20 Dec 1987 & - & Low & 28 May 1997 & 0.27 & Low \\
\hline 20 Apr 1988 & 5 & Moderate & 18 Oct 1997 & - & Very High \\
\hline 16 Oct 1988 & 15 & High & $15 \operatorname{Jan} 2000$ & - & Low \\
\hline 12 Mar 1990 & - & Low & 9 Dec 2002 & - & Low \\
\hline 20 Oct 1990 & 35 & High & $27-31$ Oct 2002 & - & Moderate \\
\hline 22 Mar 1991 & - & Moderate & 3 Nov 2002 & - & Low \\
\hline Mar 93 & - & High & 15 Dec 2003 & - & Low \\
\hline Oct 93 & - & High & 5 Feb 2004 & - & Low \\
\hline 1 Jan 1994 & - & Moderate & 29 Dec 2004 & - & Low \\
\hline 2 Nov 1994 & - & Moderate & 24 Oct 2008 & - & Low \\
\hline 17 Nov 1996 & - & Moderate & $17-18 \operatorname{Jan} 2010$ & - & High \\
\hline $14 \operatorname{Jan} 1997$ & - & Moderate & & & \\
\hline
\end{tabular}

thickness and composition of each layer are shown in Figure 2, which illustrates hydrogeological cross sections in the study area [39] [40] [41].

The Quaternary aquifer in the Wadi Watir delta is an unconfined aquifer in which the water depths range from 2.4 to $40.8 \mathrm{~m}$ [41]. The fresh water layer with a salinity of less than $2500 \mathrm{ppm}$ attains a thickness ranging between $12 \mathrm{~m}$ near the outlet of the wadi to approximately $7 \mathrm{~m}$ in the middle part of the Wadi Watir delta, while values reach to about $4 \mathrm{~m}$ near the shoreline. Groundwater over pumping from the Wadi Watir delta aquifer has caused seawater intrusion that is controlled to some extent by factors such as the distance from the shoreline, hydraulic conductivity, and aquifer recharge conditions. The first water table map was constructed based on measurements of water levels from October to November 1994 by Himida (1994) [4], while the recent water level contour map was constructed based on measurements of water levels from October to November 2012 by Eissa et al. (2013) [40]. Generally, groundwater flows from the northwestern to southeastern parts of the Wadi Watir delta, and the absolute groundwater level ranges between 0 to $2.5 \mathrm{~m}$ above mean sea level (amsl) (see Figure 3(a) and Figure 3(b)). The groundwater hydraulic gradient in the study area varies between $2.3 \times 10^{-4}$ in the south and $2.7 \times 10^{-3}$ in the north with an average value of about $1.5 \times 10^{-3}$.

The hydraulic conductivity map was created based on the results of the pumping tests that had been carried out by the Desert Research Center [4]. As shown in Figure 4, the values of hydraulic conductivity ranged between 1 and 

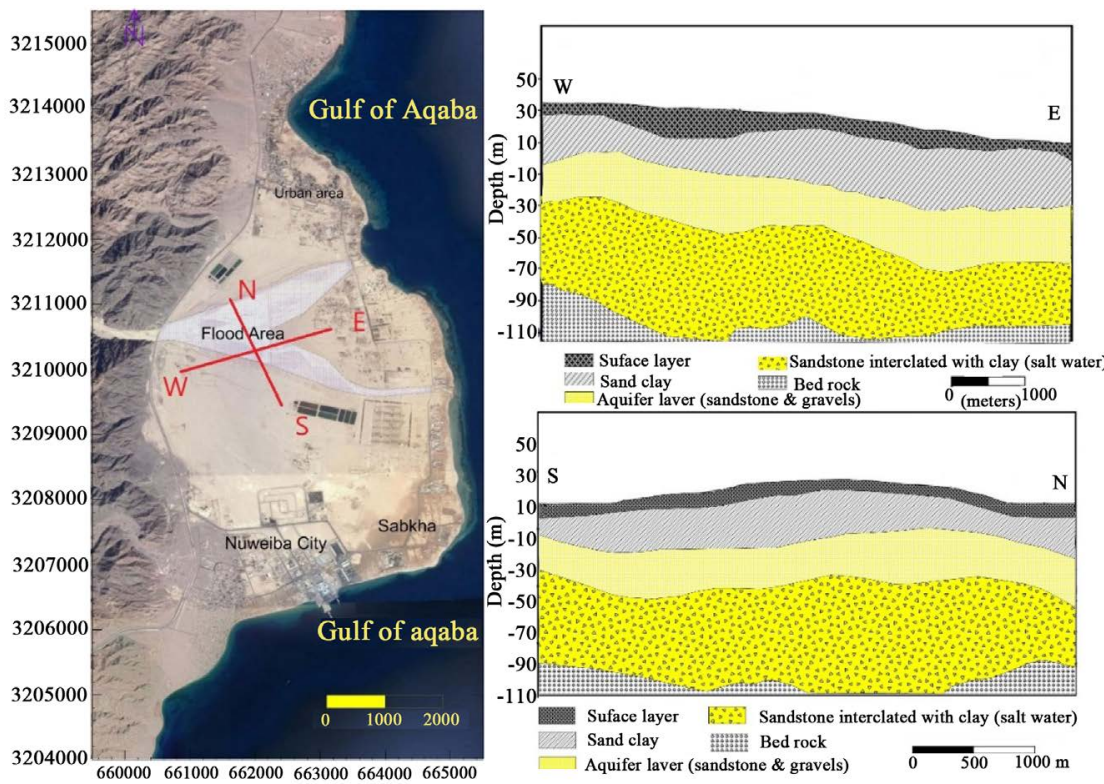

Figure 2. Hydrogeological cross sections showing that the upper two surface layers are composed of heterogeneous alluvial deposits with thicknesses generally less than $10 \mathrm{~m}$, and the third layer is sandy clay with a thickness between 30 and $45 \mathrm{~m}$. The fourth layer ranges between 20 and $40 \mathrm{~m}$ thick and is comprised of sand and gravel, while the fifth layer is comprised of sand interlayered with clay and ranges between 20 and $50 \mathrm{~m}$ thick.

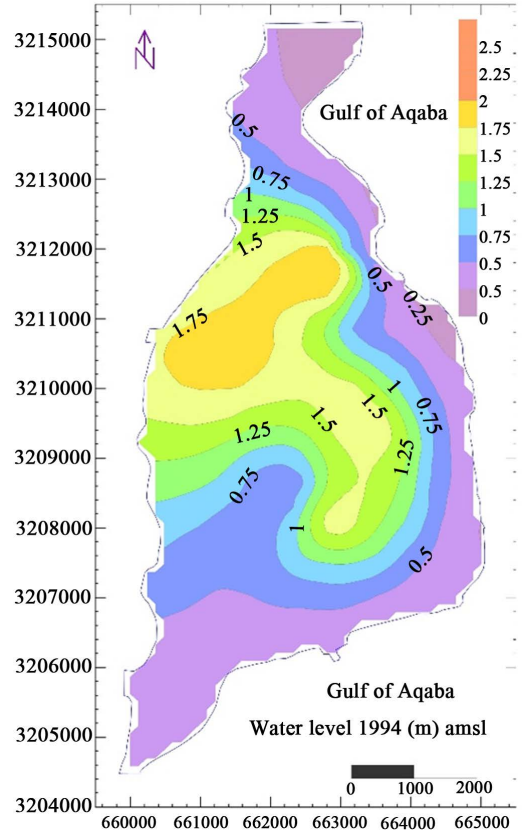

(a)

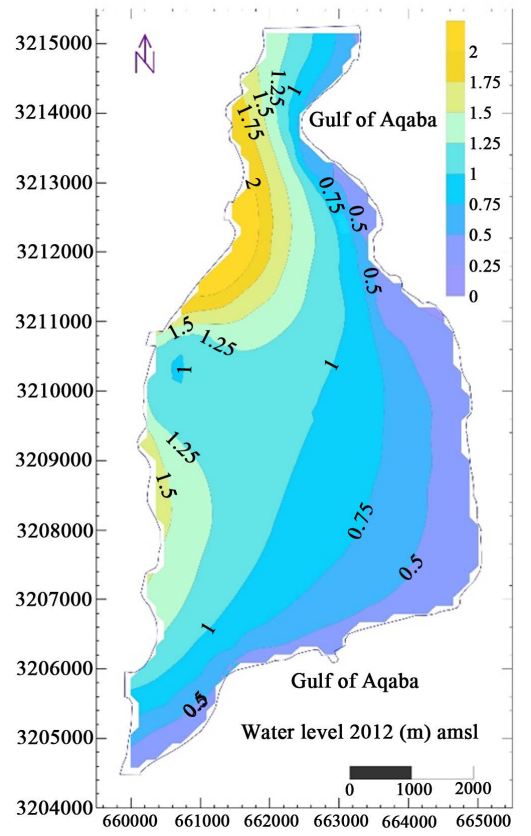

(b)

Figure 3. (a) Water level contour map of the study area in the year 1994 (after Himda, 1994); the water levels range from $2.5 \mathrm{~m}$ (amsl) near the outlet of the wadi to $1.5 \mathrm{~m}$ (amsl) in the middle part of the Wadi Watir delta, while levels are $0 \mathrm{~m}$ at the shoreline. (b) Water level contour map of the study area in the year 2012 (after Eisa, 2013); water levels range from $2.2 \mathrm{~m}$ (amsl) near the north of the wadi outlet to $1 \mathrm{~m}$ (amsl) in the middle part of the Wadi Watir delta, while levels are $0 \mathrm{~m}$ at the shoreline. 


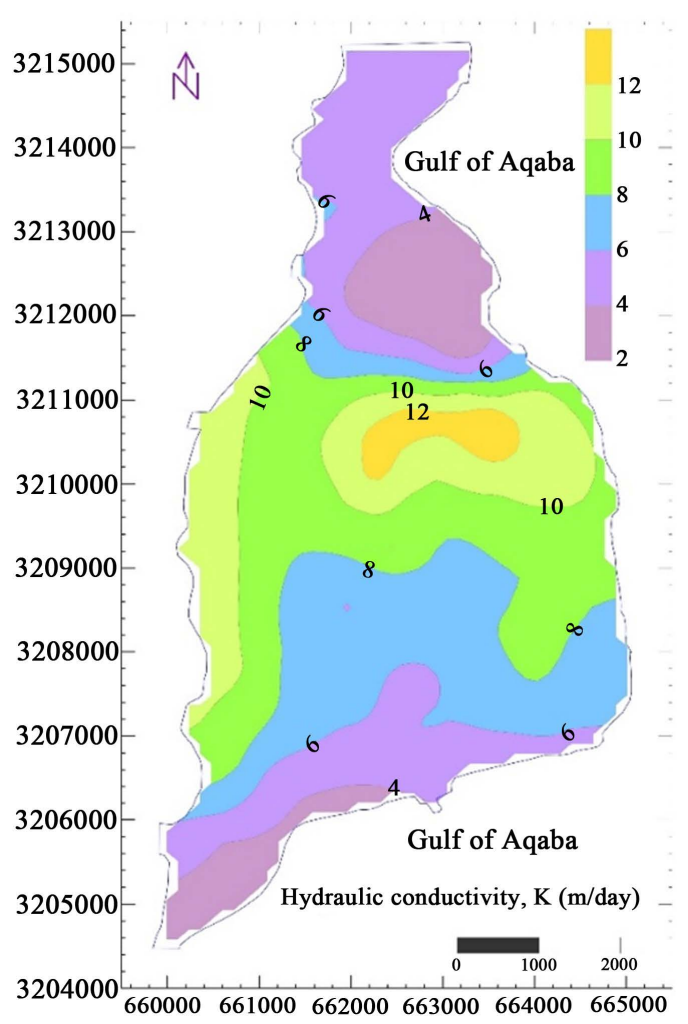

Figure 4. Hydraulic conductivity contour map in the study area, where low values (less than $4 \mathrm{~m} /$ day) were found in the north and south and high values (more than $12 \mathrm{~m} /$ day) were observed at the central part of the Wadi Watir delta.

$12 \mathrm{~m} /$ day. Low values were found in the south and high values were observed at the central part of the Wadi Watir delta, whereas moderate values were observed in northern localities. The storativity of the water-bearing horizon in the Wadi Watir delta was estimated to vary between $3.16 \times 10^{-4}$ and 0.01 . The groundwater salinity map was created based on measurements taken in 75 shallow dug wells and deep wells distributed throughout the Wadi Watir delta. As shown in Figure 5, the values of groundwater salinity ranged between 2000 ppm and 8000 $\mathrm{ppm}$. Low values of groundwater salinity were detected in the west at the wadi outlet and high values were observed at the eastern and southern parts of the Wadi Watir delta [34] [40].

\subsection{Groundwater Recharge and Pumping}

Groundwater natural recharge values have been estimated by many researchers such as [4] [5] [35] [36] [42] [43] [44]. The pumping rates in the study area varied through the period 1982 to 2012 depending on the groundwater availability and flash flood intensity and/or frequency. The average groundwater recharge in the Wadi Watir delta ranged between $3900 \mathrm{~m}^{3} /$ day (1982 to 1987) to 7770 $\mathrm{m}^{3} /$ day (1987 to 2002) with an annual daily average of $6000 \mathrm{~m}^{3} /$ day through the period from 1982 to 2009 (see Table 2). However, for each hand dug wells (40 hand dug wells), the pumping rates ranged between 0.5 and $7 \mathrm{~m}^{3} /$ day [40]. 


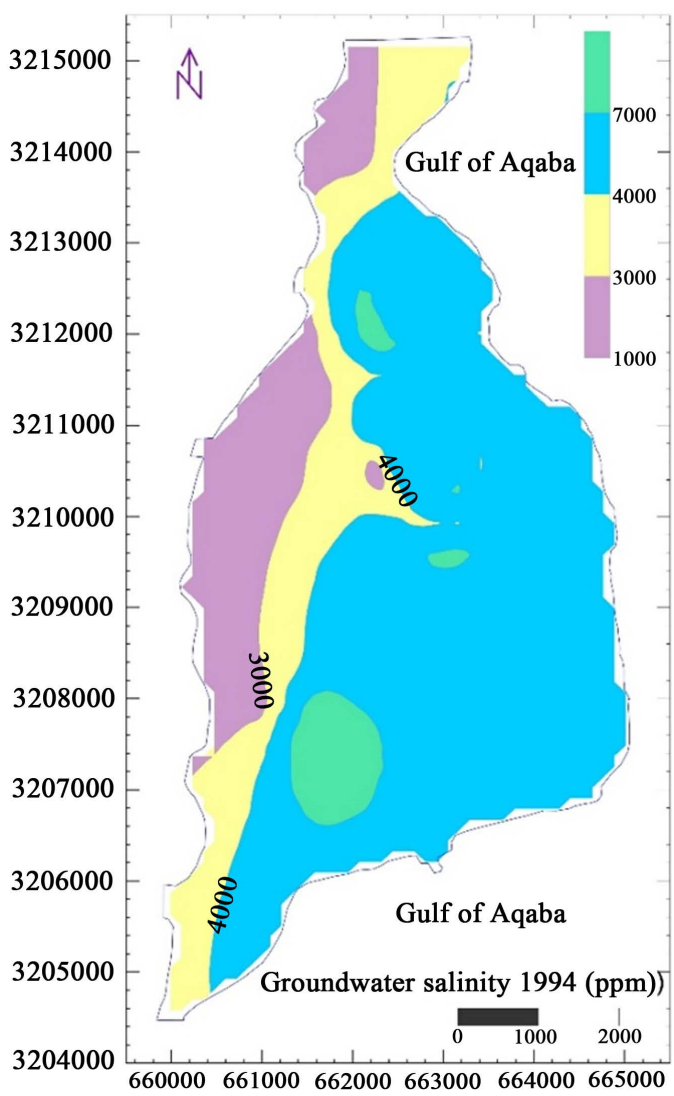

Figure 5. Groundwater salinity contour map in the study area, where low values (less than $3000 \mathrm{ppm}$ ) were found in the west and high values (more than $4000 \mathrm{ppm}$ ) were observed at the middle and eastern parts of the Wadi Watir delta.

Table 2. The amount of groundwater pumped from water supply wells on the delta (after Eissa et al., 2013).

\begin{tabular}{|c|c|c|}
\hline Period & No. of Working Wells & Withdrawal $\mathrm{Q} \mathrm{m}^{3} /$ Day \\
\hline Feb 1982 to Feb 1986 & 1 & 870 \\
\hline Feb 1986 to Jun 1987 & 4 & 3640 \\
\hline Jun 1987 to Dec 1994 & 5 & 3900 \\
\hline Dec 1994 to Dec1998 & 5 & 2500 \\
\hline Dec 1998 to Dec 2001 & 6 & 1600 \\
\hline Dec 2001 to Dec 2008 & 6 & 1600 \\
\hline Dec 2008 to Apr 2009 & 5 & 1400 \\
\hline Apr 2009 to Apr 2013 & 5 & 1400 \\
\hline
\end{tabular}

\section{Groundwater Flow Model}

\subsection{Conceptual Model}

To assess the hydrogeological suitability of installing ASR systems in the Wadi Watir delta, a numerical groundwater flow and transport model was developed to simulate the horizontal and vertical groundwater movement and upward mi- 
gration of deep saline groundwater due to groundwater pumping and seawater intrusion; then, simulations of the mixing process between injected water and ambient groundwater were conducted because this process is one of the main factors governing the recovery efficiency in ASR systems. Finite-difference code MODFLOW linked to the particle tracking code MODPATH and solute transport code MT3DMS (Codes link

https://www.usgs.gov/mission-areas/water-resources/science/modflow-and-relat ed-programs?qt-science_center_objects=0\#qt-science_center_objects) were used; all three codes were run by using the graphical user interface. Visual MODFLOW flex 6 ,

(https://www.waterloohydrogeologic.com/introducing-visual-modflow-flex-6-0) which is capable of simulating the groundwater flow in cases of injection and recovery water, was also used. MODPATH uses the average linear velocity calculated from heads that are generated by MODFLOW to track the movement of imaginary particles that are added to the injected water by advection. These particles were tracked throughout the duration of the storage and recovery cycles [45]. In order to quantify the volume of injected water recovered from the aquifer, the transport code MT3DMS was used to calculate the concentrations of water in the aquifer while considering both advection and dispersion and assuming that the aquifer is an equivalent porous medium with connected pore space; the code also assumes miscible flow and no density effects.

In the horizontal direction, an orientation grid (100 rows $\times 50$ columns) along the north-south axes and east-west axes of the modeled area was created (see Figure 6), while in the vertical direction, the model grid consisted of two layers. The first layer with a hydraulic conductivity of $4 \mathrm{~m} /$ day represents the alluvial deposits, and the second layer was comprised of Pliocene to Pleistocene aged sand with a hydraulic conductivity from 4 to $12 \mathrm{~m} /$ day [34]. For each layer, the vertical hydraulic conductivity values were assumed to be one-tenth of the values of the horizontal ones. Aquifer materials were assumed to be homogeneous and mainly composed of poorly sorted sand, silt, gravel, and clay; hence, the total

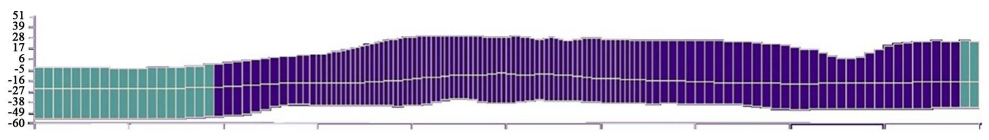

$-\mathrm{A}$

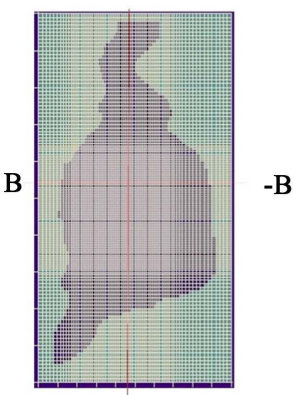

A
Cross section A-A

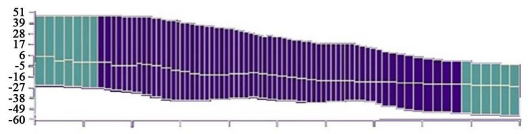

Cross section B-B

Figure 6. Developed model mesh and cross sections for the study area. 
porosity was set to 0.1 [46] [47]. The storage coefficient value used for the model ranged from $3.16 \times 10^{-4}$ to 0.01 ; also, the longitudinal dispersivity was assumed to be homogeneous and set to $10 \mathrm{~m}$, the ratio of horizontal transverse dispersivity to longitudinal dispersivity was assumed to be 0.1 , and the ratio of vertical transverse dispersivity to longitudinal dispersivity was assumed to be 0.01 [48].. The diffusion coefficient was assumed to be $9-10 \mathrm{~cm} / \mathrm{s}$ [40]. The $10-\mathrm{m}$ longitudinal dispersivity according to Gelhar (1992) was located within the category of high confidence in the small-scale field suite $(1-1000 \mathrm{~m})$ and in the category of low confidence for the entire scale of the Wadi Watir delta (for large scales of $10^{3}-10^{6} \mathrm{~m}$ ) according to contaminant events tracer tests [48].

\subsection{Boundary and Initial Conditions}

The model base was assumed to be the NO flow boundary, and for the flow and transport model, the constant head boundary was set to sea level at the shoreline, where the constant concentration was assumed to be 41,000; meanwhile, the western boundary was set to the source points boundary with a concentration value of $1000 \mathrm{ppm}$ [40]. An initial water level map for the steady state was created from the values of the water levels that were measured in February 1986 [37]. Steady state conditions of groundwater flow and solute transport models were identified from simulations under initial conditions until reaching system stabilization and equilibrium for salt and physical flow within the models. The groundwater salinity values, which were obtained from the steady state, were modified with the salinity data for deep saline groundwater from an earlier study [34], where salinity reached $18,000 \mathrm{ppm}$ at a depth of $34 \mathrm{~m}$ below sea level. In accordance with the data availability, simulations were carried out for the period from 1982 to 2012. Figure 7 shows the boundary condition observation points and abstraction wells for both the flow and transport models.

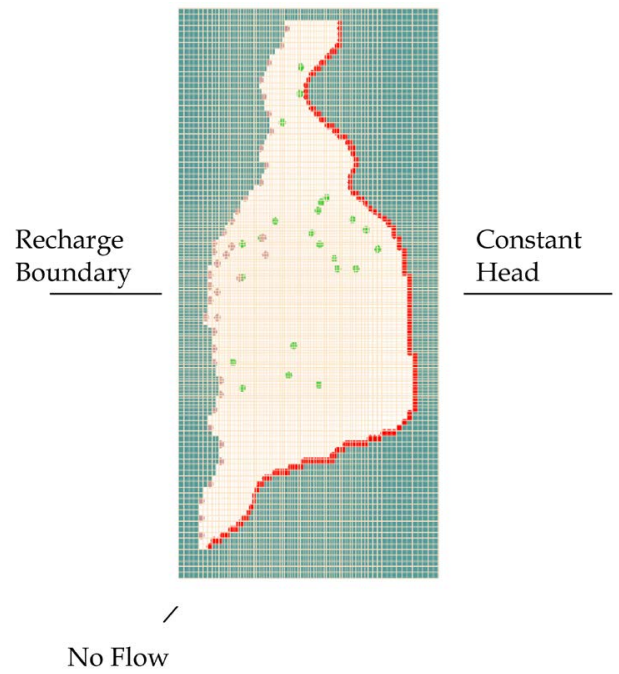

Figure 7. Model boundary conditions. The constant head boundary was set to sea level at the shoreline, and the constant concentration was assumed to be $41,000 \mathrm{ppm}$; the western boundary was set to the source points boundary with a concentration value of $1000 \mathrm{ppm}$. 
The natural recharge in the model area was assumed to be zero because the annual average rainfall for the Wadi Watir area only ranges from $10 \mathrm{~mm} /$ year in the Wadi Watir delta to $50 \mathrm{~mm} /$ year in the highland areas [35]. On the other hand, the main recharge to the aquifer comes mainly from subsurface groundwater flow from the mountain blocks [5] [49], and the main source of subsurface recharge is flash floods that occur on average about every six years [4].

\subsection{Model Calibration and Validity}

The comprehensive groundwater flow and solute transport model that was developed was calibrated by obtaining general agreement between the observed and modeled salinity and water level values; this model was found to be more sensitive to porosity, hydraulic conductivity, and dispersivity values than the other factors. The recharge was the main factor controlling the head, while the recharge rates, pumping rates, dispersivity, and effective porosity were the main factors controlling the salinity. A total of 37 head observations [5] [34] [40] were used to calibrate the model in addition to the salinity observations (see Figure 8). The pumping rate through the drilled wells changed with time ( $8 \%$ to $15 \%$ ) for each stress period through the modeled time (1982 to 2012) according to the original data that were collected. The model calibration was complete when a reasonable value of the relative error of less than $10.5 \%$ was achieved between the modeled and observed water levels. The sensitivity of the model was tested to the full range of hydrogeological and operational parameters. The model was found to be valid for most regions within the model area except for the area close to the coast and the area located in the Sabkha deposits.

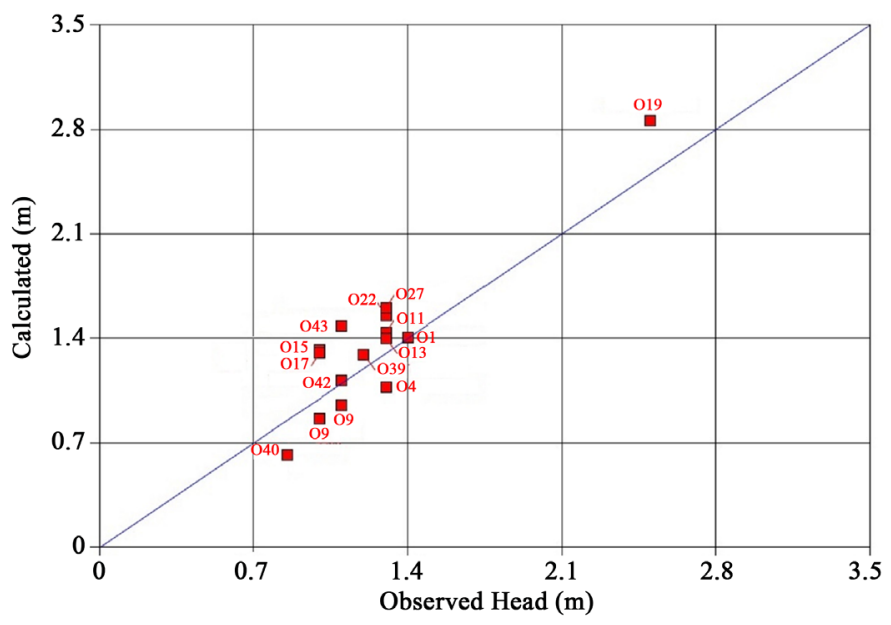

Figure 8. Measured versus model calculated water levels in cells in the groundwater flow model that contained wells. The relatively high error values obtained between the measured and simulated heads mainly can be attributed to the highly transient state throughout long-time periods, which occurred because of extensive pumping through the drilled wells located close by with in-between distances ranging from 250 to $500 \mathrm{~m}$. Moreover, the flat-water level in the Wadi Watir delta, where the maximum water level relative to sea level was $2.4 \mathrm{~m}$ and the minimum was $0.21 \mathrm{~m}$, with a mean average value of $1 \mathrm{~m}$, made it difficult to obtain head observations that matched the calculated ones. 


\section{Results}

The calibrated numerical model that was developed was used to evaluate the effects of hydrogeological and operational parameters on the recovery efficiency of ASR systems at five proposed locations in the study area (see Figure 9); these parameters included the regional hydraulic gradient, hydraulic conductivity, effective porosity, dispersivity, storage period, and volume of injected water. The mixing of injection water with ambient groundwater was also evaluated, where the salinity of the injected water was assumed as 1000 ppm, while the salinity of the ambient groundwater was assumed as $2500 \mathrm{ppm}$. Because the estimation of the recovery efficiency depends on the salinity of the recovered water, the recovered water salinity limits was set to $150 \%$ of the injected water salinity, where the $150 \%$ limit refers to the point at which recovery has ended because the concentration of recovered water reached $150 \%$ of that of injected water.

\subsection{Effect of the Hydrogeological Parameters}

The ASR systems were simulated in five specific locations in the Wadi Watir

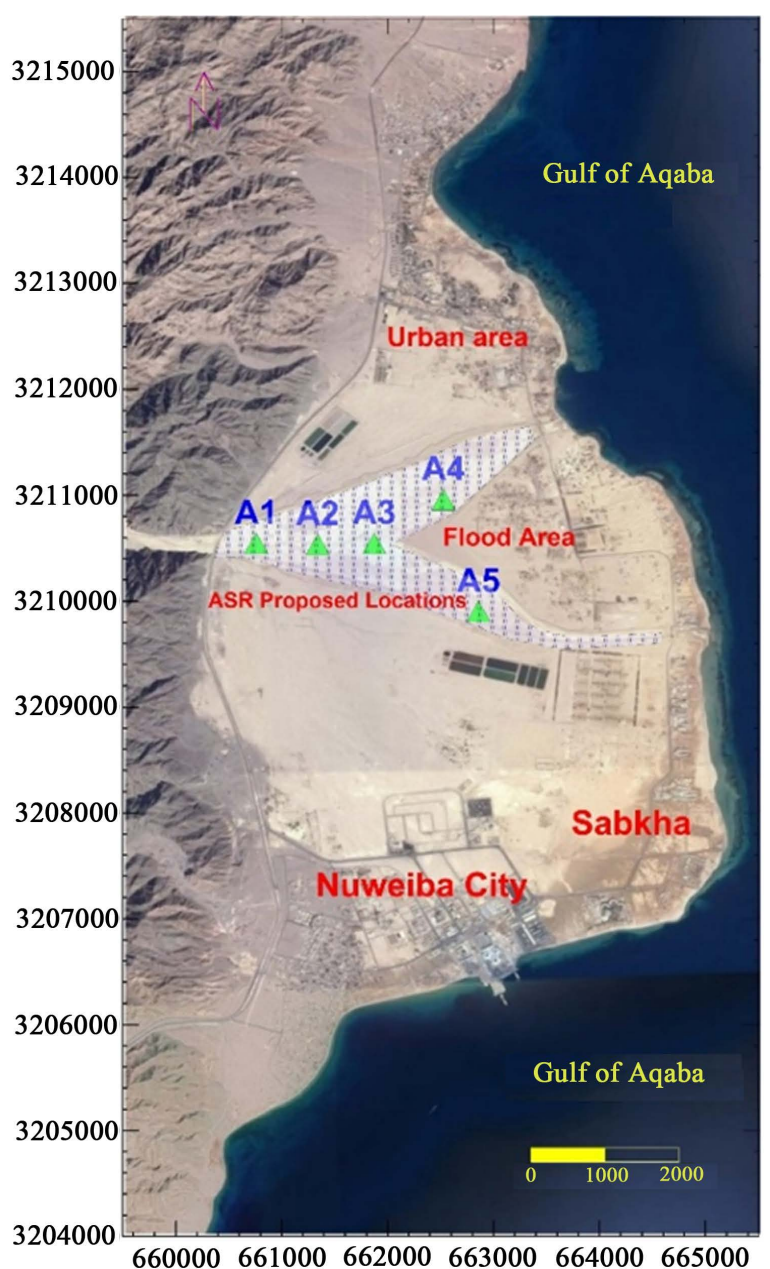

Figure 9. The proposed sites for testing the ASR systems; sites were selected in the flood zone and far from the Gulf of Aqaba, near Sabkha and the urban area. 
delta by using different injection rates. The relative effects of selected hydrogeological parameters on the recovery efficiency were similar to those discussed by Lowry (2004) [50]. Notably, the dispersivity that describes the mixing process was one of the hardest parameters to quantify in terms of the recovery efficiency impacts in ASR systems. Thus, the effects of recovered water salinity on the recovery efficiency of ASR systems were evaluated at the five locations with different dispersivity values of $3,10,20,50,100$, and $200 \mathrm{~m}$. Figure 10 shows the effects of dispersivity on the recovery efficiency of the aquifer model with a total volume of injected water of $12,000 \mathrm{~m}^{3}$ and a storage period of 180 days.

\subsection{Effect of the Operational Parameters}

The main operational parameters that affected the recovery efficiency were the storage period and the volume of injected water, as shown in Figure 11, where the recovery efficiency decreased as the storage period increased; Figure 12 shows that the recovery efficiency initially increased as the injected water volume increased, but then it decreased with large volumes of injected water because of the high hydraulic gradients created by water moving away rapidly from the ASR areas.

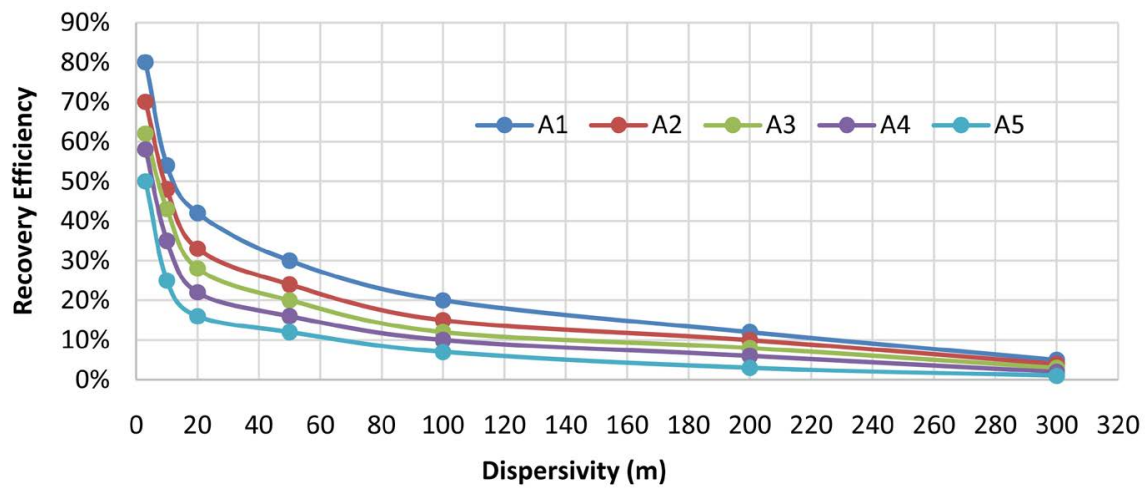

Figure 10. Effect of dispersivity on the recovery efficiency of the aquifer model with a total volume of injected water of $12,000 \mathrm{~m}^{3}$ and a storage period of 180 days.

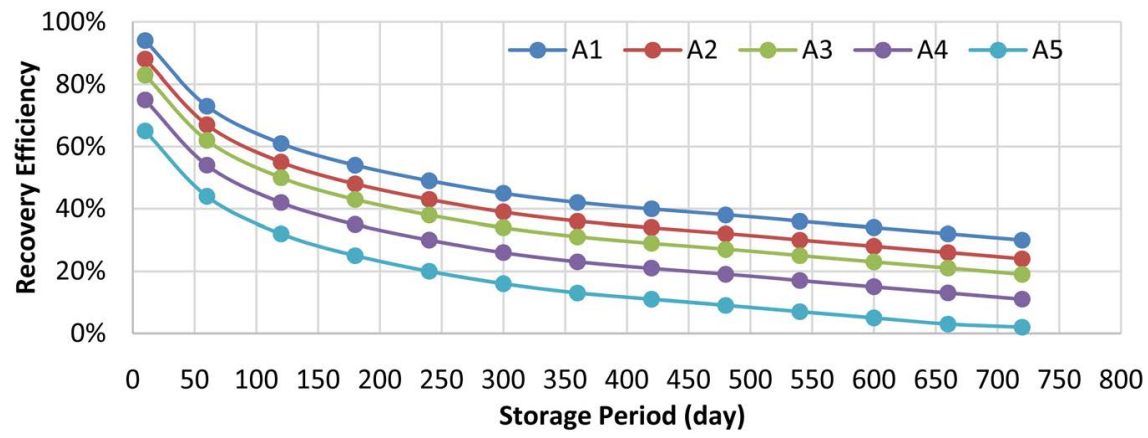

Figure 11. Comparison of the effect of the storage period on the recovery efficiency at five locations with a longitudinal dispersivity of $10 \mathrm{~m}$, volume of injected water of 12,000 $\mathrm{m}^{3}$, and a recovery concentration limit of $150 \%$ of injection water All simulations included the effects of advection and dispersion. 


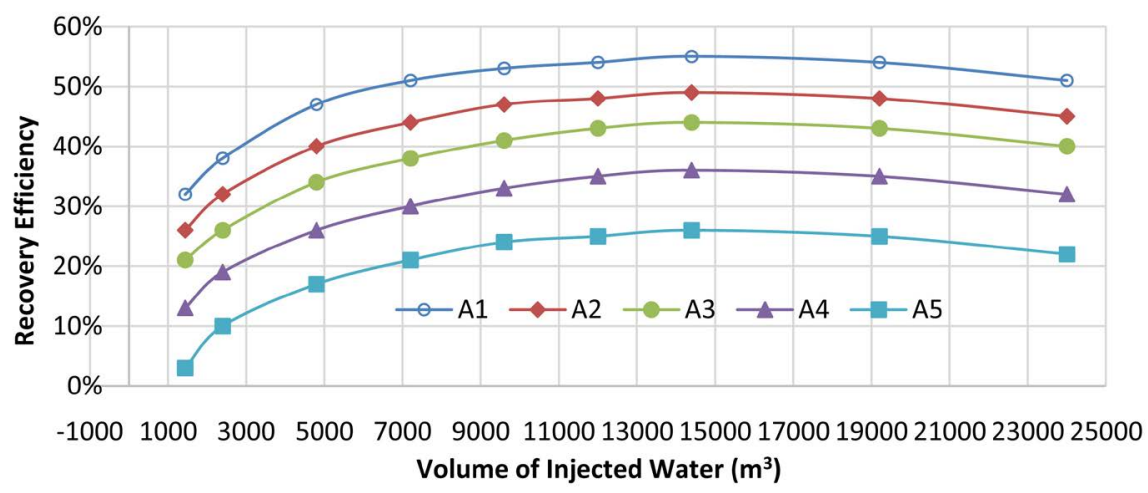

Figure 12. Comparison of the effect of the volume of injected water on the recovery efficiency at five locations with a longitudinal dispersivity of $10 \mathrm{~m}$, storage period of 180 days, and a recovery concentration limit of $150 \%$ of injection water. All simulations included the effects of advection and dispersion. Table 3 shows that the recovery efficiency of the ASR systems at the five locations ranged from 25\% (at A5) to 54\% (at A1) with a longitudinal dispersivity of $10 \mathrm{~m}$, volume of injected water of $12,000 \mathrm{~m}^{3}$, and storage period of 180 days.

Table 3. The ASR recovery efficiency at selected locations in the study area. Results show that the recovery efficiency of the ASR systems in the study area was generally low for specific injection quantities and storage periods, and the recovery efficiency was highest in area $\mathrm{A} 1$ and lowest in areas close to the sea because of the impact of sea water intrusion and the lack of thickness of the target storage layer.

\begin{tabular}{cccccc}
\hline Parameter & A1 & A2 & A3 & A4 & A5 \\
\hline Injected layer thickness (m) & 10 & 7 & 5 & 4 & 4 \\
Hydraulic gradient & 0.0004 & 0.0004 & 0.00063 & 0.00047 & 0.00047 \\
Hydraulic conductivity (m/day) & 9 & 10 & 11 & 11 & 9 \\
Dispersivity (m) & 10 & 10 & 10 & 10 & 10 \\
Period of storage (day) & 180 & 180 & 180 & 180 & 180 \\
Volume of injected water $\left(\mathrm{m}^{3}\right)$ & 12,000 & 12,000 & 12,000 & 12,000 & 12,000 \\
Volume of recovered water at salinity & 5840 & 5760 & 5160 & 4200 & 300 \\
limit 150\% of injected water $\left(\mathrm{m}^{3}\right)$ & & & & $35 \%$ & $25 \%$ \\
Recovery efficiency & $54 \%$ & $48 \%$ & $43 \%$ & $35 \%$ \\
\hline
\end{tabular}

\section{Conclusions and Recommendations}

- Although the salinity of recovered water depends on the mixing process between the injected water and ambient groundwater, the dispersivity that describes this mixing process is one of the hardest parameters to quantify.

- Using coupled numerical groundwater flow and solute transport models is an effective tool for predicting the effects of mixing between the injected water and ambient groundwater in assessments of the recovery efficiency of ASR systems.

- The groundwater aquifer in the study area is not suitable as a strategic water storage site for ASR systems because the thickness of the water storage layer is relatively small and the distance to the sea is very close; consequently, it is 
recommended that alternative artificial recharge systems be developed with existing technology to replenish the groundwater aquifer in the Wadi Watir delta.

- More research is required to evaluate the effective porosity that is inversely related to groundwater velocity and directly affects the recovery efficiency as well as the dispersivity, which is a difficult parameter to quantify as it can vary over a much smaller range than the other parameters and directly affects the recovery efficiency.

\section{Conflicts of Interest}

The author declares no conflicts of interest regarding the publication of this paper.

\section{References}

[1] Harden, B. (1996) A River Lost: The Life and Death of the Columbia. W.W. Norton \& Company, New York, London, $271 \mathrm{p}$.

[2] Alley, W.M., Healy, R.W., LaBaugh, J.W. and Reilly, T.E. (2002) Flow and Storage in Groundwater Systems. Science, 296, 1985-1990. https://doi.org/10.1126/science.1067123

[3] Mohammedjemal, A. (2006) Assessment of Artificial Groundwater Recharge Using Greenhouses Runoff (North East Naivasha, Kenya). Master Thesis, International Institute for Geo-Information Science and Earth Observation, Enschede. https://webapps.itc.utwente.nl/librarywww/papers_2006/msc/wrem/abdulwhab.pdf

[4] Himida, I.H. (1994) Water Resources in Delta Wadi Watir (Nuweiba Area) and Improvement of the Hydrologic Setting in the Area. Internal Technical Report, Desert Research Center, Cairo. (In Arabic)

[5] Ismail, Y.L. (1998) Hydrogeological and Hydro Chemical Studies on Wadi Watir Area, South Sinai, Egypt. PhD Thesis, Faculty of Science, Suez Canal University, Ismailia, $239 \mathrm{p}$.

[6] Shalaby, A.I. (1997) Geomorphology and Hydrogeology of Wadi Watir Basin, S. E. Sinai, Egypt. MSc Thesis, Faculty of Sconce, Mansoura University, Mansoura, 185 p.

[7] Himida, I.H. (1997) Water Resources of Wadi Watir. Internal Report, Desert Research Center, Cairo. (In Arabic)

[8] Pyne, R.D. (1995) Artificial Recharge and Wells. Lewis Publishers, Ann Arbor, 400 p.

[9] Vacher, H.L., Hutchings, W.C. and Budd, D.A. (2006) Metaphors and Models: The ASR Bubble in the Floridan Aquifer. Groundwater, 44, 149-154. https://doi.org/10.1111/j.1745-6584.2005.00114.x

[10] Maliva, R. and Missimer, T. (2010) Aquifer Storage and Recovery and Managed AQUIFER Recharge Using Wells: Planning, Design, and Operation. Methods in Water Resources Evaluation, Schlumberger Publisher, Sugarland.

[11] Amineh, Z.B., Hashemian, S.J. and Magholi, A. (2017) Integrating Spatial Multi Criteria Decision-Making (SMCDM) with Geographic Information System (GIS) for Delineation of the Most Suitable Areas for Aquifer Storage and Recovery (ASR). Journal of Hydrology, 551, 577-595. https://doi.org/10.1016/j.jhydrol.2017.05.031

[12] Pyne, R.D. (2005) Aquifer Storage and Recovery: A Guide to Groundwater Recharge through Wells. Second Edition, ASR Systems, Gainesville. 
[13] Brown, D.L. and Silvy, W.D. (1977) Artificial Recharge to a Freshwater Sensitive Brackish-Water Sand Aquifer, Norfolk, Virginia. United State Geological. Survey Professional Paper 939. https://pubs.usgs.gov/pp/0939/report.pdf https://doi.org/10.3133/pp939

[14] Castro, J.E. (1995) Aquifer Storage and Recovery Myrtle Beach, South Carolina; Phase II: A Hydrologic, Geochemical, and Economic Investigation. Report 7, South Carolina Department of Natural Resources, Water Resources Division, Columbia.

[15] Johnson, A.I. and Pyne, R.D.G. (1995) Artificial Recharge of Ground Water, Vol. 2. In: Proc. Second International Simpson on Artificial Recharge of Ground Water, American Society of Civil Engineers, New York, 101-108.

[16] Campbell, B.G., Conlon, K.J., Mirecki, J.E. and Petkewich, M.D. (1997) Evaluation of Aquifer Storage Recovery in the Santee Limestone/Black Mingo Aquifer near Charleston, South Carolina, 1993-1995. United State Geological Survey Water Resources Report 96-4283. https://pubs.usgs.gov/wri/1996/4283/report.pdf

[17] Mirecki, J.E., Campbell, B.G., Conlon, K.J. and Petkewich, M.D. (1998) Solute Changes during Aquifer Storage Recovery Testing in a Limestone/Clastic Aquifer Ground Water, 36, 394-403. https://doi.org/10.1111/j.1745-6584.1998.tb02809.x

[18] Stuyfzand, P.J., Smidt, E., Zuurbier, K.G., Hartog, N. and Dawoud, M.A. (2017) Observations and Prediction of Recovered Quality of Desalinated Seawater in the Strategic ASR Project in Liwa, Abu Dhabi. Water, 9, 177. https://doi.org/10.3390/w9030177

[19] Brown, C.J., Weiss, R., Verrastro, R. and Shulbert, S. (2005) Development of an Aquifer Storage and Recovery (ASR) Site Selection Suitability Index in Support of the Comprehensive Everglades Restoration Project. Journal of Environmental Hydrology, 13, 1-13.

[20] Nasiri, H., Boloorani, A.D., Sabokbar, H.A.F., Jafari, H.R., Hamzeh, M. and Rafii, Y. (2013) Determining the Most Suitable Areas for Artificial Groundwater Recharge via an Integrated PROMETHEE II-AHP Method in GIS Environment (Case Study: Garabaygan Basin, Iran). Environmental Monitoring and Assessment, 185, 707-718. https://doi.org/10.1007/s10661-012-2586-0

[21] Smith, A.J. and Pollock, D.W. (2012) Assessment of Managed Aquifer Recharge Potential Using Ensembles of Local Models. Groundwater, 50, 133-143. https://doi.org/10.1111/j.1745-6584.2011.00808.x

[22] Ward, J.D., Simmons, C.T., Dillon, P.J. and Pavelic, P. (2009) Integrated Assessment of Lateral Flow, Density Effects and Dispersion in Aquifer Storage and Recovery. Journal of Hydrology, 370, 83-99. https://doi.org/10.1016/j.jhydrol.2009.02.055

[23] Woody, J.A. (2007) Preliminary Assessment of Hydrogeologic Suitability for Aquifer Storage and Recovery (ASR) in Oregon. Master's Thesis, Oregon State University, Corvallis.

[24] Chowdhury, A., Jha, M.K. and Chowdary, V.M. (2010) Delineation of Groundwater Recharge Zones and Identification of Artificial Recharge Sites in West Medinipur District, West Bengal, Using RS, GIS and MCDM Techniques. Environmental Earth Science, 59, 1209-1222. https://doi.org/10.1007/s12665-009-0110-9

[25] Hill, C. (1997) Water Supply Needs and Sources Assessment Alternative Water Supply Strategies Investigation: A Tool for Assessing the Feasibility of Aquifer Storage and Recovery. Special Publication SJ97-SP3, St. Johns River Water Management District, Palatka. http://ufdcimages.uflib.ufl.edu/WC/08/52/83/17/00001/WC08528317.pdf

[26] Rashid, N. and Almulla, A. (2005) Aquifer Storage Recovery (ASR): An Economic 
Analysis to Support Use as a Strategic Managerial Tool to Balance a City's Desalinated Water Production and Demand. Proceedings of the 5 th International Symposium on Management of Aquifer Recharge, Berlin, 11-16 June 2005, 145-150.

https://www.ircwash.org/resources/recharge-systems-protecting-and-enhancing-gr oundwater-resources-proceedings-5th

[27] Kimbler, O.K., Kazmann, R.G. and Whitehead, W.R. (1975) Cyclic Storage of Fresh Water in Saline Aquifers. Louisiana Water Resources Research Institute Bulletin 10. Louisiana State University, Baton Rouge.

[28] Yobbi, D.K. (1996) Simulation of Subsurface Storage and Recovery of Treated Effluent Injected in a Saline Aquifer, St. Petersburg, Florida. United State Geological Survey Water Resources Investigations Report 95-4271. USGS, Tallahassee.

[29] Streetly, M.J. (1998) The Use of Modelling to Predict the Behavior of ASR Systems. In: Peter, et al., Eds., Artificial Recharge of Ground Water, A.A. Balkema, Rotterdam, 263-267.

[30] Moulder, E.A. (1970) Freshwater Bubbles: A Possibility for Using Saline Aquifers to Store Water. Water Resources Research, 6, 1528-1531.

https://doi.org/10.1029/WR006i005p01528

[31] Merritt, M.L. (1986) Recovering Fresh Water Stored in Saline Limestone Aquifers. Ground Water, 24, 516-529. https://doi.org/10.1111/j.1745-6584.1986.tb01031.x

[32] Bakker, M. (2010) Radial Dupuit Interface Flow to Assess the Aquifer Storage and Recovery Potential of Saltwater Aquifers. Hydrogeology Journal, 18, 107-115. https://doi.org/10.1007/s10040-009-0508-1

[33] Pavelic, P., Dillon, P. and Robinson, N. (2005) Modelling of Well-Field Design and Operation for an Aquifer Storage Transfer and Recovery (ASTR) Trial. Proceedings of the 5 th International Symposium on Management of Aquifer Recharge, Berlin, 11-16 June 2005, 134-138.

https://www.ircwash.org/resources/recharge-systems-protecting-and-enhancing-gr oundwater-resources-proceedings-5th

[34] El-Refaei, A.A. (1992) Water Resources of Southern Sinai, Egypt. Geomorphological and Hydrological Studies. PhD Thesis, Faculty of Science, Cairo University, Cairo, $357 \mathrm{p}$.

[35] Cools, J., Vanderkimpen, P., El Afandi, G., Abdelkhalek, A., Fockedey, S., El Sammany, M., Abdallah, G., El Bihery, M., Bauwens, W. and Huygens, M. (2012) An Early Warning System for Flash Floods in Hyper-Arid Egypt. Natural Hazards and Earth System Sciences, 12, 443-457. https://doi.org/10.5194/nhess-12-443-2012

[36] JICA (1999) South Sinai Groundwater Resources Study in the Arab Republic of Egypt. Final Report, El-Qanater El-Khayria, National Water Research Center, Cairo.

[37] El-Kiki, M.F., Eweida, E.A. and El-Refeai, A.A. (1992) Hydrogeology of the Aqaba Rift Border Province. Proceeding of the Third Geology of Saini Conference, Ismailia, 91-100.

[38] El-Shazly, E.M., Abddel-Hady, M.A., El-Ghawaby, M.A., El-Kassas, I.A. and El-Shazly, M.M. (1974) Geology of Sinai Peninsula from ERTS 1 Satellite Images Remote Sensing Research Project. Academy of Scientific Research and Technology, Cairo.

[39] Abbas, A.M., Atya, M.A., Al-Sayed, E.A. and Kamei, H. (2013) Assessment of Groundwater Resources of the Nuweiba Area at Sinai Peninsula, Egypt by Using Geoelectric Data Corrected for the Influence of Near Surface in Homogeneities. Journal of Applied Geophysics, 56, 107-122. https://doi.org/10.1016/j.jappgeo.2004.04.002 
[40] Eissa, M.A., Thomas, J.M., Pohll, G., Hershey, R.L., Dahab, K., Dawoud, M.I., El-Shiekh, A. and Gomaa, M.A. (2013) Groundwater Resource Sustainability in the Wadi Watir Delta, Gulf of Aqaba, Sinai, Egypt. Hydrogeology Journal, 21, 1833-1851. https://doi.org/10.1007/s10040-013-1031-y

[41] Khalil, M.H. (2010) Hydro-Geophysical Configuration for the Quaternary Aquifer of Nuweiba Alluvial San. Journal of Environmental and Engineering Geophysics, 15, 77-90. https://doi.org/10.2113/JEEG15.2.77

[42] Idris, H. (1995) Springs in Egypt. Environmental Geology, 27, 99-104. https://doi.org/10.1007/BF01061678

[43] Issar, A. and Gilad, D. (1982) Groundwater Flow System in the Arid Crystalline Province of Southern Sinai. Hydrological Sciences Journal, 27, 309-325. https://doi.org/10.1080/02626668209491112

[44] Milewski, A., Sultan, M., Yan, E., Becker, R., Abdeldayem, A., Soliman, F. and Gelili, K. (2009) A Remote Sensing Solution for Estimating Runoff Recharge in Arid Environments. Journal of Hydrology, 373, 1-14. https://doi.org/10.1016/j.jhydrol.2009.04.002

[45] Lowry, C.S. and Anderson, M.P. (2006) An Assessment of Aquifer Storage Recovery Using Ground Water Flow Models. Ground Water, 44, 661-667. https://doi.org/10.1111/j.1745-6584.2006.00237.x

[46] Fetter, C.W. (2001) Applied Hydrogeology. 4th Edition, Prentice-Hall, Inc., Upper Saddle River, $621 \mathrm{p}$.

[47] Johnson, A.I. (1976) Specific Yield Compilation of Specific Yield for Various Materials. United States Geological Survey Water-Supply Paper 1662-D. https://pubs.usgs.gov/wsp/1662d/report.pdf

[48] Gelhar, L.W., Welty, C. and Rehfeldt, K.W. (1992) A Critical Review of Data on Field-Scale Dispersion in Aquifers. Water Resource Research, 28, 1955-1974. https://doi.org/10.1029/92WR00607 https://www.academia.edu/28388251/A_critical_review_of_data_on_field-scale_dis persion_in_aquifers

[49] El-Ghazawi, M.M. (1999) Reconsideration of Hydrogeologic Setting in the Delta of Wadi Watir, Southern Sinai. Bulletin of Science, Mansoura University, Egypt, 26.

[50] Lowry, C.S. (2004) Assessment of Aquifer Storage Recovery: Defining Hydraulic Controls on Recovery Efficiency at Three Representative Sites in Wisconsin. Master Thesis, Department of Geology and Geophysics, University of Wisconsin, Madison. https://www.wri.wisc.edu/wp-content/uploads/FinalWR03R005.pdf 